\title{
WASTE ELIMINATION USING VALUE STREAM MAPPING AND VALSAT
}

\author{
Dion Avellino Suyanto dan Sunday Noya \\ Department of Industrial Engineering, FST, Ma Chung University \\ e-mail: 411010008@student.machung.ac.id, sunday.alexander@machung.ac.id
}

\begin{abstract}
Fierce competition encourages companies to make continuous improvements to achieve better working efficiency. One method to improve the working efficiency is using the concept of lean manufacturing. The efficiency of the existing work in PT. Rimba Kencana is still not good because there are many processes that are not uniform and because of that, production lead time is increased. By using value stream mapping and value stream analysis tools (VALSAT), the production processes in the company are mapped into the current state mapping and future state mapping. In the current state mapping, the total value of production lead time is 59.49 days and the value of process cycle efficiency (PCE) is $0.013 \%$. After doing improvement on welding department, the total value of production lead time decreased to 48.22 days and the value of process cycle efficiency becomes $0.016 \%$.
\end{abstract}

Keywords: Efficiency, Value Stream Mapping, Value Stream Analysis Tools

\begin{abstract}
ABSTRAK
Persaingan bisnis yang semakin ketat mendorong perusahaan untuk terus melakukan perbaikan secara berkelanjutan untuk mencapai efisiensi kerja yang baik. Salah satu metode untuk meningkatkan efisiensi kerja adalah dengan menggunakan konsep lean manufacturing. Efisiensi kerja yang ada di PT. Rimba Kencana masih kurang baik karena masih banyaknya proses yang tidak seragam dan memunculkan production lead time. Dengan menggunakan value stream mapping dan value stream analysis tools (VALSAT), proses kerja yang ada di perusahaan dipetakan ke dalam current state mapping dan future state mapping. Pada current state mapping total nilai production lead time adalah 59.49 hari dan nilai process efficiency cycle (PCE) adalah 0.013\%. Setelah melakukan perbaikan pada departemen welding, total nilai production lead time menjadi 48.22 hari dan nilai process efficiency cycle menjadi $0.016 \%$.
\end{abstract}

Kata Kunci: efisiensi, value stream mapping, value stream analysis tools

\section{INTRODUCTION}

Nowadays, the competition in the industry is growing, demanding the industry to conduct continuous improvement. By making continuous improvement, the industry will be able to maintain the effectiveness and efficiency of each performance. Especially with the free trade conducted in Indonesia, the industry must be prepared to meet global competition.

Table 1 shows the growth in the bus industry. From the year 2006 to the year 2012 the bus industry in Indonesia posted steady growth that can be seen from the increasing number of buses produced. Specifically in the year 2009, production of buses has decreased because of the global crisis in 2008 and impact the bus production in 2009 [1]. The percentage classified as moderate, which is about $21 \%$.

With the growth in the number of bus production, the supporting components industry will also be affected. The components industry supplying the technical components required on the bus like recliner, seating, mirrors, and others.
Table 1. Amount of Domestic Bus

\begin{tabular}{cc}
\multicolumn{2}{c}{ Production [2] } \\
\hline Year & Amount (unit) \\
\hline 2006 & 1254 \\
2007 & 1676 \\
2008 & 2956 \\
2009 & 2328 \\
2010 & 4106 \\
2011 & 4142 \\
2012 & 5299 \\
\hline
\end{tabular}

The good work application is required and continues to improve efficiency in order to meet the competition. One method to improve the work efficiency is to use the concept of lean manufacturing. Lean manufacturing concepts taken from the Toyota Production System (TPS) that can be used to reduce the cost of goods production. With the smaller the cost of production, companies will gain more profits and can attract many customers because the small production costs will affect the selling price of the product. 
The analysis taken is to map the current conditions that exist in the company by creating a value stream mapping for current conditions. With the current state map that has been created, the value added time and production lead time can be measured. Then, VALSAT matrix will be used to choose which one is the most suitable tool to overcome the problems that was encountered. After that the design of improvements will be made and finally the future state mapping will be made that gives the improvement percentage achieved by the company when applying the proposed improvements.

\section{LITERATURE REVIEW}

Lean concept is one business systems concept that is quite popular in the United States. Lean concept is based on the Toyota management system that has been developed and expanded.

This lean approach is a systematic method to identifying and eliminating waste or activities that are not adding value (non-value added activities) through continuous improvement. This is conducted by flowing the product, whether raw materials, intermediate goods, and finished goods, as well as information using a pull system of internal and external customers to pursue the excellence [3].

Value stream is the flow of activities, both value added and non-value added which is required to process a product through the production stream from raw materials to customers and the design flow from concept to implementation. The focus of value stream mapping is the process of value-added and nonvalue added [4].

\section{RESEARCH METHODS}

Field observation is directly conducted to find the problems that exist in the company and understand in general about the production process in the company. During the observation, the problems that were encountered are still many WIP (Work in Process) lying in many places and in the area around the workstation and of course will impact on the higher production lead time and causing waste.
The next phase is to conduct elemental breakdown to break down activities into smaller work elements. Then calculate the cycle time and perform the uniformity test of the data to discard data that is not uniform. From the uniform data obtained, the next step is to calculate the workers performance rating that will be used in the calculation of normal time. Then determine the allowance and calculate standard time for each work station.

From the standard time obtained, the current state mapping made is used to view the total production lead time and the total value added time. The next step is the selection of an appropriate tool through the selection VALSAT matrix to identify wastes that were encountered. Based on the proposed improvements from the tool selected from the VALSAT matrix, Future state mapping was made and the next step is to make the Implemented Current State Mapping to see the total production lead time and the total value added time on the improvements that are implemented in the company and calculated the percentage of improvement obtained.

\section{RESULTS AND DISCUSSION}

The production processes of the recliner RCL241 part begin from cutting the pipes, axles, plates, as well as the manufacture of plastic A and plastic B. For the raw material such as the pipes and axles, the machine that was used to cut is band saw machine and then gets into the CNC machine to be formed. Large plate will be cut using scissors engine and produces smaller plate. This small plate will go to the stamping machine to form the desired part. For axle B and axle $\mathrm{C}$, after entering into the CNC machine, the part will be forwarded to the welding of plate A. While axle $A$ and pipes welding process will be forwarded to the welding plate B (workstation 1) together with the plate B generated from the stamping machine. Plate $\mathrm{C}$ which also generated from the stamping machine will be forwarded to workstation 2 welding plate $\mathrm{B}$. Then, plate $\mathrm{A}$ and plate $\mathrm{B}$ generated from the welding process will be immersed in the pretreatment process to prepare parts for further processing. The next process is the powder coating process that aims to give color to the part. Part that has been given 
through the process of powder coating, will be assembled together with plastic A and plastic B resulting from the injection molding process.

The cycle time of each work station is described in the table below after going through the process of disposal of data in the process of testing the uniformity of data:

Table 2. Testing the Uniformity of Data

\begin{tabular}{|c|c|c|c|c|}
\hline No. & Proces & Name & $\begin{array}{l}\text { The number } \\
\text { of samples } \\
\text { that are not } \\
\text { uniform }\end{array}$ & $\begin{array}{l}\text { Cycle } \\
\text { time (s) }\end{array}$ \\
\hline \multirow{3}{*}{1} & \multirow{3}{*}{ Bandsaw } & Axle A & 2 & 27.38 \\
\hline & & Axle B & 2 & 24.74 \\
\hline & & Pipe & 3 & 157.17 \\
\hline \multirow{4}{*}{2} & \multirow{4}{*}{ CNC } & Axle A & 2 & 50.90 \\
\hline & & Axle B & 2 & 51.47 \\
\hline & & Axle C & 0 & 55.73 \\
\hline & & Pipe & 3 & 46.22 \\
\hline 3 & Cutting & & 2 & 28.16 \\
\hline \multirow{2}{*}{4} & Injection & Plastic A & 2 & 55.35 \\
\hline & Molding & Plastic B & 1 & 60.01 \\
\hline \multirow{5}{*}{5} & \multirow{5}{*}{ Stamping } & Plate A & 4 & 22.77 \\
\hline & & Plate B & 5 & 39.28 \\
\hline & & Plate C & 0 & 4.80 \\
\hline & & Plate D & 0 & 5.86 \\
\hline & & Plate E & 5 & 19.31 \\
\hline 6 & \multicolumn{2}{|c|}{ Welding Plate A } & 2 & 116.61 \\
\hline 7 & \multicolumn{2}{|c|}{ Welding Plate B I } & 2 & 68.90 \\
\hline 8 & \multicolumn{2}{|c|}{ Welding Plate B II } & 2 & 19.86 \\
\hline 9 & \multicolumn{2}{|c|}{ Phosphating } & 3 & 60.00 \\
\hline \multirow{3}{*}{10} & \multirow{3}{*}{$\begin{array}{l}\text { Powder } \\
\text { Coating }\end{array}$} & Plate A & 2 & 15.78 \\
\hline & & Plate B & 2 & 16.57 \\
\hline & & Plate D & 2 & 74.14 \\
\hline 11 & Assembly & & 2 & 57.32 \\
\hline
\end{tabular}

Next, the normal time is calculated of each process by multiplying the cycle time with the performance rating.

Table 3. Calculation of Normal Time

\begin{tabular}{rlccc}
\hline No. & \multicolumn{1}{c}{ Process } & $\begin{array}{c}\text { Cycle } \\
\text { Time } \\
(\mathrm{s})\end{array}$ & $\begin{array}{c}\text { Value } \\
\text { of PR }\end{array}$ & $\begin{array}{c}\text { Normal } \\
\text { time } \\
(\mathrm{s})\end{array}$ \\
\hline 1 & Bandsaw & 209.29 & 0.99 & 207.20 \\
2 & CNC & 55.73 & 1.11 & 61.86 \\
3 & Cutting & 28.16 & 1.01 & 28.44 \\
4 & Stamping & 18.40 & 1.17 & 21.53 \\
5 & Welding Plate A & 116.61 & 1.13 & 131.77 \\
6 & Welding Plate B I & 68.90 & 0.93 & 64.07 \\
7 & Welding Plate B II & 19.86 & 1.13 & 22.44 \\
8 & Phosphating & 1.00 & 1.02 & 1.02 \\
9 & Powder coating & 43.37 & 1.21 & 52.48 \\
10 & Injection molding & 57.68 & 1.08 & 62.29 \\
11 & Assembly & 57.32 & 1.31 & 75.09 \\
\hline
\end{tabular}

Then the standard time of each process is calculated by considering the allowance as in the table below:

Table 4. Determination of Standard Time

\begin{tabular}{clccc}
\hline No. & \multicolumn{1}{c}{ Process } & $\begin{array}{c}\text { Normal } \\
\text { time (s) }\end{array}$ & $\begin{array}{c}\text { Allowance } \\
(\%)\end{array}$ & $\begin{array}{c}\text { Standard } \\
\text { time (s) }\end{array}$ \\
\hline 1 & Bandsaw & 207.20 & 15 & 238.28 \\
2 & CNC & 61.86 & 13 & 69.90 \\
3 & Cutting & 28.44 & 15 & 32.71 \\
4 & Stamping & 21.53 & 31 & 28.21 \\
5 & Welding Plate & & & \\
& A & 131.77 & 19 & 156.80 \\
6 & Welding Plate & & & \\
& B I & 64.07 & 19 & 76.25 \\
7 & Welding Plate & & & \\
& B II & 22.44 & 19 & 26.70 \\
8 & Phosphating & 1.02 & 17 & 1.19 \\
9 & Powder & & & \\
& coating & 52.48 & 22 & 64.03 \\
10 & Injection & & & \\
& molding & 62.29 & 16 & 72.26 \\
11 & Assembly & 75.09 & 18 & 88.60 \\
\hline
\end{tabular}

From the information of the standard time that has been obtained, the current state mapping can be made based on current conditions in the company. From the current state mapping, the total value-added time is 715.71 seconds and the total production lead time is 59.49 days.

The next step is to choose the right tool from VALSAT matrix. The following table (Table 5) is the calculation of the VALSAT matrix.

Based on the above table, it can be seen the tool that has the highest value is the Process Activity Mapping. From the activities at each work station, total activity of value added (VA) types are 48 activities, the type of non-value added activities are 2 activities, and the types of Necessary but non-value added activities are 92 activities. The improvements that can be proposed are:

1. In the stamping process of plate $A$, plate $B$, and plate $\mathrm{E}$, the cycle time can be minimized by designing the process as a continuous process. The continuous process is doing the process from the raw material to shape the finished part desired. In this way, the transportation time will be eliminated. 


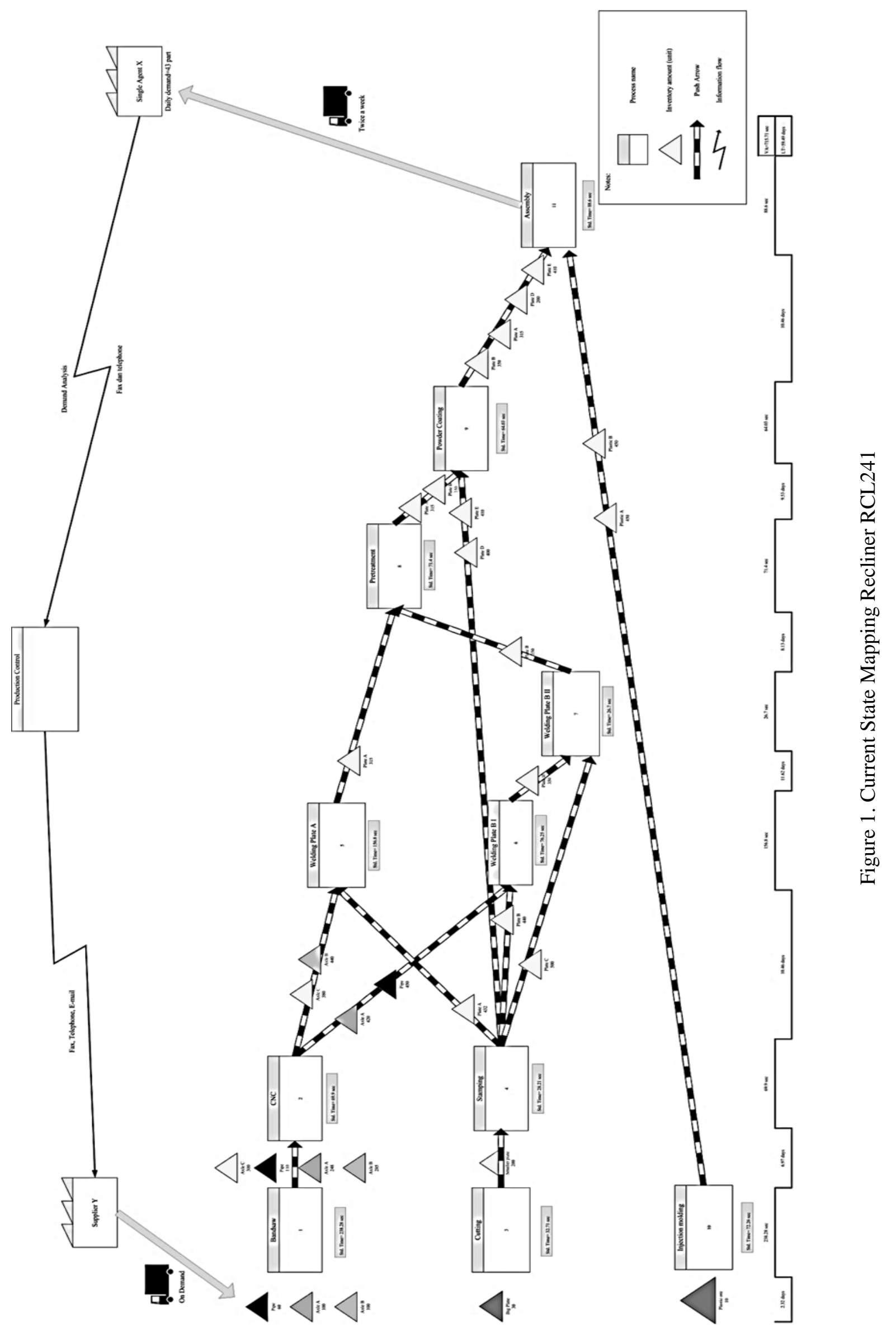


Table 5. Calculation of VALSAT Matrix

\begin{tabular}{|c|c|c|c|c|c|c|c|c|}
\hline \multirow[b]{2}{*}{ Waste type } & \multirow[b]{2}{*}{ Score } & \multicolumn{7}{|c|}{ Tools } \\
\hline & & PAM & SCRM & PRF & QFM & DAM & DPA & PS \\
\hline Overproduction & 1.59 & 1.59 & 4.77 & - & 1.59 & 4.77 & 4.77 & - \\
\hline Waiting & 1.68 & 15.14 & 15.14 & 1.68 & - & 5.05 & 5.05 & - \\
\hline Transportation & 1.32 & 11.86 & - & - & - & - & - & 1.32 \\
\hline $\begin{array}{l}\text { Inappropriate } \\
\text { processing }\end{array}$ & 1.55 & 13.91 & - & 4.64 & 1.55 & - & 1.55 & - \\
\hline Inventory & 1.86 & 5.59 & 16.77 & 5.59 & - & 16.77 & 5.59 & 1.86 \\
\hline Motion & 1.00 & 9.00 & 1.00 & - & - & - & - & - \\
\hline Defect & 1.00 & 1.00 & - & - & 9.00 & - & - & - \\
\hline Total sco & & 58.09 & 37.68 & 11.91 & 12.14 & 26.59 & 16.95 & 3.18 \\
\hline
\end{tabular}

Table 6. Operator Performance Rating Of Welding Process Implementation

\begin{tabular}{|c|c|c|c|c|}
\hline Process & Rating category & Symbol & Value & Reason \\
\hline \multirow{4}{*}{$\begin{array}{l}\text { Welding } \\
\text { plate B }\end{array}$} & Skill & B2 & 0.08 & Operator has enough skill in the process of welding the plate $B$ \\
\hline & Effort & B2 & 0.08 & Operator looks vibrant in trying to finish the job \\
\hline & Working & & & The condition around is quite noisy and work area is not very \\
\hline & $\begin{array}{l}\text { Condition } \\
\text { Consistency }\end{array}$ & $\begin{array}{l}\mathrm{E} \\
\mathrm{B}\end{array}$ & $\begin{array}{c}-0.03 \\
0.03\end{array}$ & $\begin{array}{l}\text { tidy } \\
\text { The consistency of the operator is good }\end{array}$ \\
\hline & Total & & 0.16 & \\
\hline
\end{tabular}

2. At the welding process of plate $B$, both workstations are combined so that it will be able to eliminate transportation time and WIP between workstations.

3. The process of calculating the plate will be better not done. However, this calculation process moved along with the installation process on the hanger.

4. In the powder coating plate $\mathrm{D}$ and plate $\mathrm{E}$, it will be better when finished the installation process on hanger, the workers immediately transport it nearby the hook. In this way, the transportation process can be minimized.

5. In the powder coating process of plate $A$ and plate $B$, it would be better to use 2 hands rule. In this way, the installation processing time will be minimized significantly. With assumption, the installation process cycle time calculation is reduced to half of the initial processing time.

From the improvement proposed, activities in PAM table are sorted and obtained the total activity of value added (VA) types are 48 activities, the type of non-value added activities successfully eliminated, and the types of Necessary but non-value added activities decreased to 72 activities. At the time of implementation, the improvements made in the department of welding results in new cycle time are 65.05 seconds. To calculate the normal time on new processes that are implemented, then the performance rating is done as the Table 6 .

Based on the performance rating, the normal time of welding process of plate $\mathrm{B}$ can be calculated as below:

$$
\text { Normal time }=65.05 \times 1.16=75.46 \mathrm{sec}
$$

Determination of the allowance that is used in the calculation of standard time can be seen in the Table 7.

Based on the obtained value of allowances, standard time of welding process of plate $\mathrm{B}$ can be calculated:

$$
\text { Standard time }=75.46 \times 1.19=89.79 \mathrm{~s}
$$

From the standard time data that has been obtained, the Current State Mapping implementation can be seen in Figure 2 with the assumption that the other standard time equal to the standard time at the beginning CVSM. Based on CVSM implementation, initial production lead time is reduced from 60.65 days to 50.19 days. Initial Value added time is also reduced from 715.71 seconds to 689.01 seconds. 


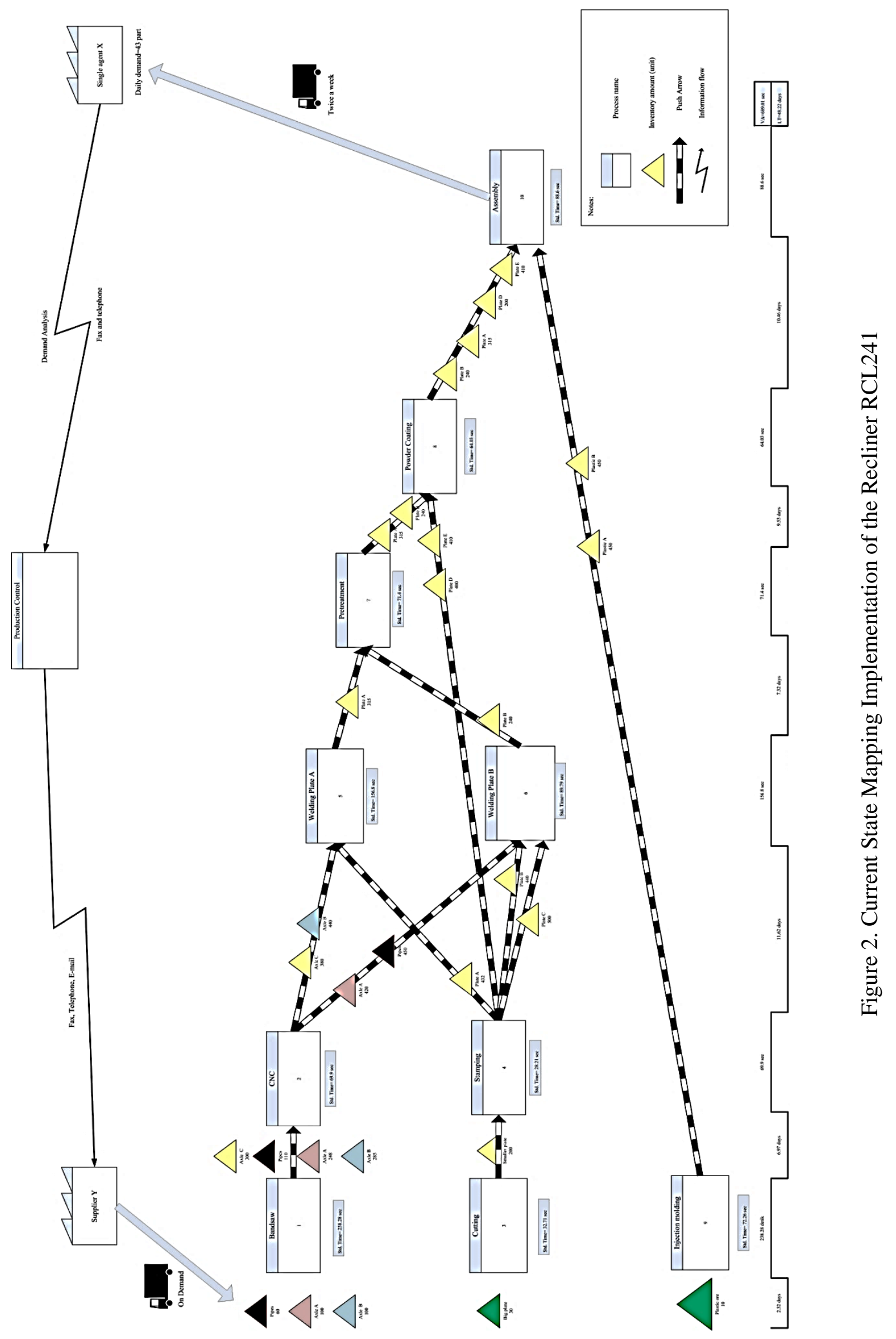


Table 7. Allowance Value of Welding Plate B Implementation

\begin{tabular}{clcc}
\hline Process & \multicolumn{1}{c}{ Allowance factor } & Allowance (\%) & Total \\
\hline Welding & Personal needs: man & 1 & \\
plate B & Effort needed: very low & 6 & \\
\hline \multirow{4}{*}{ Welding } & Working position: standing on two legs & 1 & \\
& Work movement: Somewhat limited & 1 & \\
plate B & Eye fatigue: discontinuous view & 3 & $19 \%$ \\
& Atmosphere: enough & 2 & \\
& Environmental condition: very noisy & 3 & \\
& Inevitable obstacles & 1 & \\
\hline
\end{tabular}

Based on the data from the production lead time and value added time obtained in CVSM implementation, it can be seen that the production lead time is reduced but the value added time value also decreases. To know the advantages gained by the company in terms of work efficiency, we can calculate the value of the PCE. In CVSM implementation PCE value is $\frac{689.01 \mathrm{sec}}{4166208 \mathrm{sec}}=0,016 \%$, and the prefix CVSM PCE value is $\frac{715.71 \mathrm{sec}}{5139936 \mathrm{sec}}=0,013 \%$. There is no significant increase in the PCE values obtained, because the improvement that are implemented directly in the company only applied to one department only, specifically the welding department. Potential considerable improvements will be obtained when applied to all the work departments.

\section{CONCLUSSION}

Based on the research that has been done, the takt time of the company is $\mathbf{5 0 2 . 3 3}$ seconds and all of the work process is still below the takt time. This allows to do the process of merging in existing workstations. In the assessment given to the seven kinds of waste in the value stream analysis tools matrix (VALSAT), the most suitable tool is the use of process activity mapping (PAM). From the sorting activity types that exist in the PAM, it can be seen there are still many non-valueadded activities with the type of Necessary but non-value added (NNVA) activities is 92 activities, the number of types non-value added activities (NVA) is 2 activities, and types of value added (VA) is 48 activities. Based on the design of the proposed improvements, NNVA types were reduced to 72 activities, NVA types successfully eliminated, and the VA type is the same.

At the current state mapping, value added time and total production lead time of the process are 715.71 seconds and 59.49 days respectively. In the current state of implementation mapping, the value added time and total production lead time is 689.01 seconds and 48.22 days respectively. When compared value added time at current time mapping the initial state and implementation state, there is also reduction in value adding time to the product. However, from the process cycle efficiency view, the improvement that is implemented can be considered beneficial for the company. Initial value of process cycle efficiency is $0.013 \%$ and the value of process cycle efficiency in improvement implementation is $0.016 \%$. If the improvements are applied in all work departments, then the company will gain higher process cycle efficiency value.

\section{REFERENCES}

[1]. A. P. I. Lestari, N. L. Ayuningtyas, and V. B. Fladian, Dampak Krisis Global Terhadap Ketenagakerjaan di Indonesia, (Online), 2013, (http://ekonomi.kompasiana.com/bisnis/2 013/12/02/dampak-krisis-global-terhadapketenagakerjaan -di-indonesia613237.html, accessed March $1^{\text {st }}$ 2014).

[2]. Badan Pusat Statistik, Produksi Kendaraan Bermotor Dalam Negeri (unit) 2008-2012, (Online), 2012, (http://www.bps.go.id/tab_sub/view.php? kat=2\&tabel=1\&daftar $=1$ 
\&id_subyek=09\&notab=13, accessed February $28^{\text {th }}$ 2014).

[3]. Gaspersz V., 2007, Lean Six Sigma for Manufacturing and Service Industries, PT. Gramedia Pustaka Utama, Jakarta.
[4]. Rother M., Shook J., 1999, Learning to See, Lean Enterprise Institute, Brookline. 